heid briefwisseling naast verslagen van de Raad van Bestuur en de Algemene Vergaderingen. De werkingsverslagen vertonen lacunes die evenwel opgevangen worden door uitgebreide dossiers met betrekking tot de werking. Het archief is vrij toegankelijk mits toestemming van de dienstdoende archivaris.

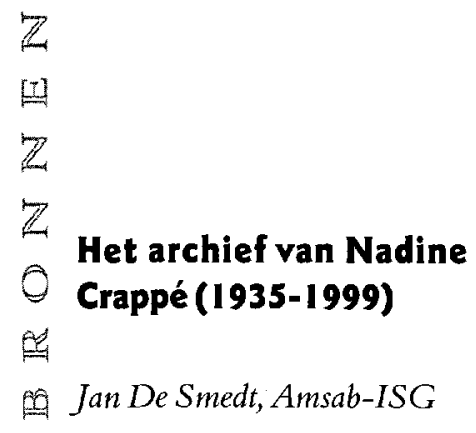

Nadine Crappé is geboren in Gent op 29 oktober 1935. Ze behaalt het diploma technicus in de scheikunde aan de Nijverheidsschool en wordt in 1956 de eerste vrouwelijke hoofdlaborante bij het chemische bedrijf UCB-SIDAC. Ze lijdt aan chronische reuma, maar door de medische vooruitgang kan ze vanaf de tweede helft van de jaren 1960 terug normaal functioneren.

In 1968 stelt ze zich een eerste keer verkiesbaar voor de ondernemingsraad en begint een carrière als ABVV-militante. Daarnaast is ze actief in de vrouwencommissie van het ABVV en staat ze mee aan de wieg van de Gentse Dolle Mina-beweging. Militeren voor vrouwenrechten stuit in die tijd op heel wat tegenkanting, ook in vakbonds- en socialistische kringen; ze krijgt als BBTK-militante aftershave als 1-meicadeautje ...

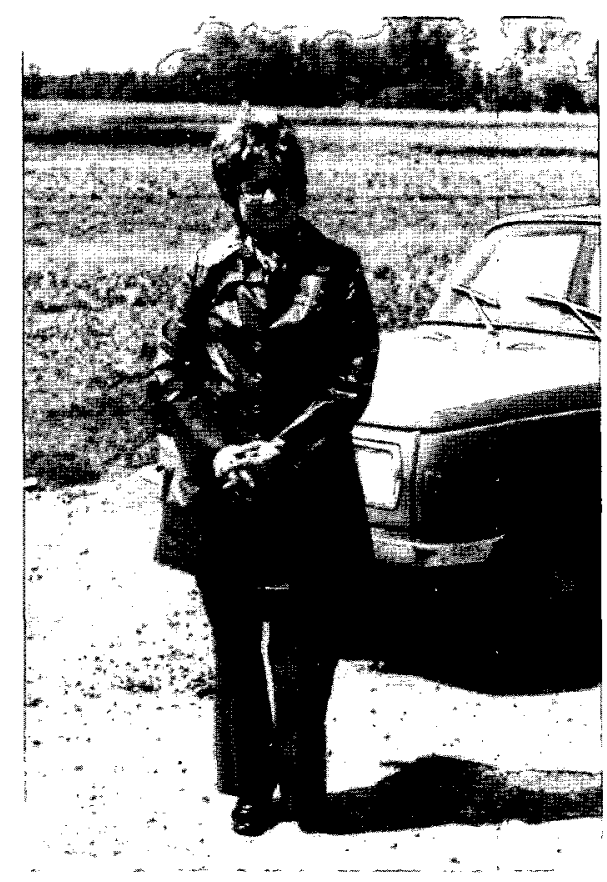

Nadine Crappé

In 1976 stapt ze uit de BSP (ze was lid sinds haar 18e) en treedt toe tot de KPB. Wel blijft ze actief in het ABVV.

Op haar 42e huwt ze Willem Van De Velde en zet haar activiteiten binnen Dolle Mina, die sinds 1975 al fel verminderd zijn, volledig stop. Tussen 1980 en 1994 is ze rechter in sociale zaken. In 1988 legt ze ook haar vakbondsactiviteiten stil en werkt ze als vrijwillig moreel consulent in de gevangenis van Gent. Ze wordt secretaris van de SMGB (Stichting voor Morele Bijstand aan Gevangenen) en verzorgt er het tijdschrift Stigma. Op 14 november 1999 overlijdt Nadine Crappé. (1)

In 1994 maakte Crappé haar persoonlijk archief over aan Amsab-ISG.

Het omvat 10 nummers in 2 dozen $(0,22$ 
lopende meter), voornamelijk dossiers met betrekking tot vrouw en arbeid, een dossier omtrent Dolle Mina in het Gentse met enkele liedjesteksten erin, (het abortuslied enz). Diverse boeken en publicaties omtrent vrouwenemancipatie zijn overgebracht naar de bibliotheek; enkele foto's en propagandamateriaal gingen naar het departement Beeld \& Geluid.

(I) Korte tijd voordien heeft Paule Verbruggen haar nog geïnterviewd. Het interwiew wordt bewaard in de bibliotheek van Amsab-ISG onder Biodoc 64/8.

2
2
2
2
2

\section{Het archief van} europarlementslid Freddy Willockx (1995-1999)

\section{Martijn Vandenbroucke, Amsab-ISG}

Freddy Willockx is zeker geen onbekende binnen het archiefdepartement van Amsab-ISG. Enkele jaren terug werd het archief van zijn regeringscommissarisperiode geïnventariseerd. In het kader van een Europees project werd vorig jaar besloten tot de ontsluiting van het archief dat hij als Europees parlementslid in de tweede helft van de jaren 1990 aanlegde.

\section{De archiefvormer}

Freddy Willockx ( ${ }^{\circ}$ Sint-Niklaas, 2 september 1947) studeerde economie aan de Gentse universiteit en werd er assistent van professor Van Meerhaeghe. In 1973 ruilde hij zijn prille academische carrière voor een politieke en werd attaché bij het kabinet van minister van Economische Zaken Willy Claes. Twee jaar eerder was hij in zijn geboortestad verkozen tot gemeenteraadslid voor de Socialistische Partij (SP), waarmee hij meteen het jongste gemeenteraadslid van Vlaanderen was. Drie jaar later brak de SP de zetelende meerderheid, waarop Willockx opgenomen werd in het schepencollege. Hij verliet het kabinet van Willy Claes en werd algemeen secretaris van ABVV Sint-Niklaas-Dendermonde. Toen in 1977 de functie van adjunct-nationaal secretaris van de SP vrijkwam, verliet hij de vakbond en verscheen opnieuw op het nationale toneel. In 1979 werd hij verkozen tot federaal volksvertegenwoordiger. Als 'anti-cumulard' nam hij ontslag als schepen en adjunct-partijsecretaris en stortte zich op de nationale politiek. Hij had vooral aandacht voor de financiële dossiers. In mei 1980 werd hij als staatssecretaris van Financiën opgenomen in het driekleurige kabinet-Martens III. Na het verdwijnen van de liberalen in december van hetzelfde jaar werd Freddy Willockx minister van Posterijen, Telegrafie en Telefonie in de eveneens kortstondige regeringen-Martens IV (december 1980- april 1981) en -Mark Eyskens (april-september 1981). Tijdens de oppositiejaren van de SP was hij een erg bedrijvig parlementslid. Bij de terugkeer van de socialisten in de regering werd hij dan ook beloond met zijn 'oude' portefeuille van PTT in het kabinet-Martens VIII (mei 1988- september 1991). Enkele maanden later leidde Willockx de SP naar de over- 